\title{
SOLUTIONS FOR DEVELOPING HOUSEHOLD ECONOMY IN VIETNAM - A CASE STUDY IN CAN THO CITY FROM 2021 TO 2025
}

\author{
Nguyen Thi Anh ${ }^{1}$, PhanThi Phuong Linh ${ }^{2}$ and Ho Huu Tien ${ }^{3}$ \\ ${ }^{1}$ Ho Chi Minh City University of Resources and Environment \\ http://doi.org/10.35409/IJBMER.2020.3194
}

\begin{abstract}
The household economy plays a very important role in the multi-sector economy in Vietnam today. The development of the rural household economy has had positive changes in terms of scale, speed, and structure. In recent years, many households have affirmed their position against the competitive pressure of competitors in the market economy, which has a positive impact on the cause of local poverty reduction. like the whole country. However, besides the achievements, the household economy still has many limitations in sustainable development. In this study, the authors focused on analyzing and assessing the situation of household economic development in Can Tho City from 2017 to 2019 with contents such as Infrastructure Development. Socioeconomic; Application and development of science and technology; Supporting households in product consumption; Hunger eradication and poverty alleviation from a sustainable household economy aims at pointing out some limitations and shortcomings in the sustainable development of the household economy and its causes, thereby proposing some remedial measures to promote The household economy in rural areas in Can Tho City develop in the direction of efficiency and sustainability in the period from 2021 to 2025.
\end{abstract}

Keyword: Household economy, rural areas, sustainable development.

\section{INTRODUCTION}

The household economy is a business organization owned by a household in which members have a common property, contributing to the common economic activities in agricultural, forestry, and fishery production or some other products and business domains prescribed by law. (Mai ThiThanhXuan and Dang Thi Thu Hien, 2003). The family economy is a relatively common type of economy and is developed in many countries around the world. The longevity of this form of production is changing itself to become an economic component of society, making an important contribution to the socio-economic development of each country. In Vietnam, the household economy also plays a significant role and role, because our country enters a market economy with nearly $80 \%$ of the population living in rural areas with a low starting point. The household is currently a popular production unit. This is an economic model with an important position in the process of restructuring the macroeconomy, to mobilize all resources to conduct the cause of industrialization and modernization of the country.

At present, the household economy is not an economic component, but a form to distinguish it from other types of economic organizations. One of the members of the household economy is 


\section{International Journal of Business Management and Economic Review}

Vol. 3, No. 04; 2020

ISSN: 2581-4664

also the head of the household. In economic activities, the family can conduct all stages of the production and reproduction process. The head of the household manages all production and business processes and is indefinitely responsible for all his activities. In our country, the household economy develops mainly in rural areas, often called the farm household economy, in urban areas, it is called small scale handicraft households. The household economy is currently developing and operating in various fields such as agriculture, transportation, construction, trade and service, cottage industries and handicrafts, business, etc. In Vietnam, the economy Thehousehold is mainly the economy of farming households in rural areas. In terms of business structure, household economy is divided into categories: purely agricultural households (engaged in agriculture, forestry, and fishery); households cum jobs (both doing agriculture and doing handicraft activities); professional households (operating in business and service sectors); and general business households (operating in the fields of agriculture, industry, and services). Up to now, the household economy has become an important part of our multi-sector economy.

Recognizing the importance of household economic development in a multi-sector economy in our country today, especially the development of household economy in a developed city such as Can Tho City, because so the authors have chosen the research topic. "Solutions for developing household economy in Vietnam - A case study in Can Tho City from 2021 to 2025" to focus on analyzing and assessing the reality of household economic development Currently in Can Tho City over the years 2017 - 2019 to point out some limitations and shortcomings in the sustainable development of household economy and its causes, thereby proposing solutions to promote promoting household economy in rural areas to develop towards efficiency and sustainability.

\section{LITERATURE REVIEW}

\section{Household economy}

The household economy is a type of business organization owned by the household in which members have a common property and contribute capital, land, and labor resources together in production activities. agriculture or some other products and business sectors prescribed by law. In Vietnam, a household economy is a form of distinction from other forms of economic organization. The existence of the household economy mainly relies on family labor to exploit the land and other resources to develop production and legitimate enrichment. The household economy develops mainly in the countryside, often called the farm household economy, in the city called small-scale handicraft households. Rural households are mostly diversified in production and business, combining husbandry with farming, handicraft industry, and subbusiness.

\section{Development of socio-economic infrastructure}

Socio-economic infrastructure includes: technical and physical facilities, works and facilities existing on a certain territorial space, they are used as conditions for production and daily life. to ensure the smooth functioning of material, information, and service flow to meet production and living needs. Socio-economic infrastructure is divided into technical and social infrastructures. Technical infrastructure includes transportation, irrigation, communications, power supply, public lighting, water supply, sewerage, waste treatment, and other facilities. Social infrastructure includes education and training establishments, hospitals, sanitation facilities ... 


\section{International Journal of Business Management and Economic Review}

Vol. 3, No. 04; 2020

ISSN: 2581-4664

The policy of socio-economic infrastructure development has been applied by the government following the geographical location, topography, climate, and weather ... to ensure the sufficient and effective provision of conditions. service, infrastructure services for local economic development. The content of this policy is to support investment in essential works: roads, irrigation, power supply, water supply, telecommunications, etc. The objectives of this policy will impact investment promotion, creating The driving force for attracting investment to investors in the field of socio-economic infrastructure, creating favorable conditions for production and business activities of households currently engaged in economic activities.

\section{Application and development of science and technology}

The household economic production process is mainly based on manual labor and traditional tools, so most of them have low labor productivity. Moreover, the managerial and professional qualifications of the household head are very limited, mainly in the traditional manner, passed down from experience from a previous life to the next.Therefore, the head of the household is very limited in terms of laws, business, and market economy.

The contents of policies on science and technology for the household economy include Dissemination and application of new technologies for processing production; provide material services; vocational training, vocational training for farmers in terms of production techniques and economic management, knowledge of laws, markets, and international integration...

\section{Supporting households in product consumption}

In the context of market mechanisms and economic integration, competition is becoming more and more fierce. Therefore, the role of market development is more important than ever. If production development is not associated with market development to solve the "output" of consumption of products and services, it will face unpredictable risks for economic entities.

The starting point of economic production for the majority of households is still heavily selfsufficient, aiming to meet the direct consumption needs of the households. While the market is the deciding factor towards exploiting the potentials of households; The greater the orientation of household economic production to meet market demand, the greater the ability to benefit households from production activities.

The State has the policy to support the search and expansion of consumer markets for household and farm economies, which are necessary and urgent as production scale is on the rise. Market development support policies used by local governments to support household economies in finding partners and output markets for their products and services. The local government organizes activities such as exhibitions, forums, ... to create opportunities to promote products and services of the household economy to potential customers inside and outside the locality. In other words, the role of the State's supportive policy in providing timely and complete information to households about market fluctuations will help households capture new business opportunities to minimize risks "off-season"; At the same time, it is easy for households to consume products they produce ... Through market policies and support of the consumption of products by the State to help household economies adapt to the closed market mechanism. contribute to improving the efficiency of using labor resources, creating jobs in rural areas; as well as stimulating households to produce based on family farms, in the fields of agriculture forestry - fishery ... 


\section{International Journal of Business Management and Economic Review}

Vol. 3, No. 04; 2020

ISSN: 2581-4664

\section{Creating jobs and reducing poverty}

Labor and employment play an important role in social life, it is indispensable for each individual and all economic sectors, and is a core and cross-cutting issue in economic and social activities. festival. Once having a job, it is accompanied by income to poverty reduction and sustainable poverty reduction. Therefore, to meet the employment needs of the entire society, the State must have an appropriate policy on labor and employment.

Job creation involves: reorganizing labor division, shifting labor structure, and industries of households from agriculture to non-agriculture, forming households that both produce goods and provide services. , developing industry, handicrafts in rural areas to create new jobs to overcome unemployment ... At the same time, the content of poverty reduction policies for households includes credit incentives for the poor; supporting production and provision of agricultural, forestry and fishery extension services; support for vocational training, job creation, and labor export; support for housing, production land and daily-life water for poor households; legal aid for the poor; assisting social protection beneficiaries; support specific poverty reduction ...

In addition to the policies to protect rights and obligations, the State also has other policies aimed at encouraging development assistance in the form of cooperatives and other forms of association; training and fostering to raise the qualifications of the managerial and technical staff ... to properly develop production and business forms of this common economic type in our country. at the current stage; as well as contributing to the household economy, especially in rural areas, the exercise of autonomy and attention. These policies require comprehensive implementation and resolution to ensure benefits for households who are involved in household economic development.

\section{Factors affecting household economic performance}

Implementation of policies in general and implementation of household economic development policies, in particular, is always influenced and influenced by many factors on:

\section{Group of objective factors}

- Natural conditions: Natural geography and existing local capacity of the soil, water resources, climate, land ... have an objective influence on the implementation of household economic development policy.

- Objective socio-economic situation of the locality: In the economic aspect, once the local economic growth is large enough, the financial resources are strong enough to implement the policy of household economic development., the local government will focus on introducing more powerful and scalable measures to address the policy issues posed for household economic development.

In the social aspect, if in low and unequal intellectual conditions together with the customs and habits of the people in different regions, it also affects the inhibition of changing the ownership of business structure ... The higher the intellectual level, the better the people's awareness and understanding are improved; together with the formation of labor skills, it will be more and more favorable for the implementation of household economic development policy.

The challenges posed by the threat of environmental pollution caused by the negative impacts of industrialization and urbanization are now pressing issues that are significantly affecting the implementation. household economic development policy at the local level, because of policy 


\section{International Journal of Business Management and Economic Review}

Vol. 3, No. 04; 2020

ISSN: 2581-4664

issues that arise from it.

- Competitive factors and economic integration, market volatility: The trend of competition and integration, globalization has increasingly had a multidimensional impact that significantly affects the implementation of development policies. Local household economy. Besides, market volatility with input prices increased due to scarcity; or the contracts of agencies with foreign partners that are broken or pinched will affect the production and consumption of products of the people; or there are too many households producing the same products, of course, the selling price will be low, which will affect the income and livelihood of households ...

\section{Group of subjective factors}

- Institutional policies for household economic development. Completing this policy and institution to remove all obstacles and create equal and transparent competition mechanisms and environments to facilitate the liberation of productive forces and the liberation of the population through the development of the household economy. families to mobilize and effectively use all resources for development.

- The apparatus and staff of civil servants working on the policy: The quality and effectiveness of policy implementation, as well as the success of the local household economic development policy, depend greatly on The entities organizing this policy, especially, depend on the operational capacity of the State agencies (from the central to local levels) and the capacity, morality and public duties of Human resources are officials and civil servants in the process of implementing the household economic development policy. And so the nature of policy issues and the resolution of household economic development policy issues is strongly and directly affected by the ability to operate quickly or slowly, favorably or difficultly. system of operation apparatus of State agencies and officials and public servants. This must be the main group of subjects responsible for organizing the implementation of household economic development policies.

- The political commitment to action of the leaders, management, and administration of household economic development policies: The level of success of the local household economic development policy requires priority Resolutions of unanimous efforts to commit political action of leaders, management, and administration of household economic development policies to make the most of the local strengths in the organization process. Implement this policy.

- Skills, career experience of family members, knowledge in using household resources.

\section{METHODS OF RESEARCH}

\section{General objective}

The main objective of the project is to analyze and evaluate the situation of household economic development in Can Tho City in the period from 2017 to 2019 to show some limitations and shortcomings in sustainable development. Sustainability of household economy and its causes, thereby proposing solutions to promote household economy in rural areas in Can Tho City to develop in an effective and sustainable direction in the coming time.the period from 2021 to 2025.

\section{Detail objectives}

(1) Systematize the theoretical basis for household economic development;

(2) Analyze and assess the current situation of household economic development in Can Tho City from 2017 to 2019 with contents such as Socio-Economic Infrastructure Development; 


\section{International Journal of Business Management and Economic Review}

Vol. 3, No. 04; 2020

ISSN: 2581-4664

Application and development of science and technology; Supporting households in product consumption; Hunger eradication and poverty reduction from the sustainable household economy.

(3) Propose a solution to promote household economy in rural areas in Can Tho City to develop towards efficiency and sustainability in the period from 2021 to 2025.

Research subjects: Household economy in rural areas in Can Tho City.

Research scope

Spatial scope: The thesis focuses on household economic research in rural areas in Can Tho City. In particular, focusing on studying 4 main contents in household economic development in the period of 2017 - 2019 are: Developing socio-economic infrastructure; Application and development of science and technology; Support household product consumption and Poverty reduction from the sustainable household economy.

Time scope: From 2017 to 2025.

\section{Research Methods}

The thesis has used some research methods such as data collection, synthesis, analysis, and evaluation of the current situation of household economic development in Can Tho City from 2017 to 2019. with contents such as Development of socio-economic infrastructure; Application and development of science and technology; Supporting households in product consumption; Hunger eradication and poverty alleviation from a sustainable household economy aims at pointing out some limitations and shortcomings in the sustainable development of the household economy and its causes, thereby proposing solutions to promote The household economy in rural areas in Can Tho City develops in the direction of efficiency and sustainability in the period from 2021 to 2025.

\section{RESEARCH RESULTS}

The situation of household economic development in Can Tho city from 2017 to 2019 a.The actual situation of socio-economic infrastructure development

Infrastructure is an essential part of socio-economic development, including household economic development in Can Tho. The current situation of road and river transportation system is as follows:

Road transport system: The whole city of Can Tho has $2,762,84 \mathrm{~km}$ of roads, the density of $2.3 \mathrm{~km} / \mathrm{km} 2$ (if excluding commune roads, the whole city has $698,548 \mathrm{~km}$ of roads, the density of $0.5 \mathrm{~km} / \mathrm{km} 2$ ); including $123,715 \mathrm{~km}$ of national highway; $183.85 \mathrm{~km}$ of provincial roads; $332.87 \mathrm{~km}$ of district roads; $153.33 \mathrm{~km}$ of urban roads; $1,969,075 \mathrm{~km}$ of hamlets, communes, and neighborhoods. With $3.98 \%$ hot concrete pavement, $26.26 \%$ asphalt, $27.74 \%$ paved with stone, $17.44 \%$ graded, the rest is dirt roads mostly used for pedestrians and 2-wheel vehicles with tissue and small load. (Socio-economic survey report - Can Tho 2019)

River transport system: The waterway network in the area has a total length of $1.157 \mathrm{~km}$, of which about $619 \mathrm{~km}$ is capable of transporting vehicles of a tonnage of 30 tons or more (average depth> 2, 5m). Including 6 routes under central management (Hau river, Can Tho river, Cai San canal, ThiDoi canal, O Mon canal, Xa No canal) with a total length of $132.88 \mathrm{~km}$, ensuring for vehicles with tonnage from 100 - 250 tons of operation ... Four river routes are managed by the city: Thot Not canal, Ba Dam canal, CauNhieu canal, Ba Lang canal with a total length of 81.45 $\mathrm{km}$, ensuring for vehicles with payload from 30 - 50 tons of operation. The river routes managed 


\section{International Journal of Business Management and Economic Review}

Vol. 3, No. 04; 2020

ISSN: 2581-4664

by the province and district include 40 routes with a total length of $405.05 \mathrm{~km}$, ensuring the capacity of the tonnage of 15 - 60 tons to operate. (Socio-economic survey report - Can Tho 2019)

In general, the transport infrastructure system in Can Tho is well-invested and fully equipped, the system of concrete roads and concrete bridges that replace monkey bridges in inter-hamlet and inter-commune roads is quite well implemented. good. The basic transport system fully meets the needs of traveling as well as the demand for transporting goods. Besides, the system of water supply and drainage, the electricity system is also built synchronously, well serving the daily needs and production needs of the people.

\section{b. Current situation of application and development in science and technology}

Development of science and technology in production in Can Tho has been gradually implemented, especially applied to the development of a household economy based on promoting the application of advanced science and technology through technical support, production means, business guidance, legal support for the household economic households to gradually switch to businesses and cooperatives. To form neighborhood markets, concentrated trading areas, invest in the development of clean agricultural production along the direction of serving urban centers, focusing on increasing productivity, quality, and efficiency.

Increasing investment and having policies to support Thot Not district specializing in vegetable production according to VietGap standards; rationally and effectively exploiting agricultural land in O Mon, ChauThanh and Long My districts, vegetable producing households in vegetable areas are supported with training in new technology and technology. Scientific techniques to develop from alkaline land, households have started to produce and bring high economic efficiency to the family. Consolidating and improving the operation efficiency of cooperatives, gardening, and ornamental creatures

On the other hand, this policy also focuses on investment in promoting agricultural mechanization, equipping land tractors, combine harvesters, and rice dryers for agricultural cooperatives, cooperative groups, and farm households. help farmers reduce labor, increase productivity and production efficiency, reduce losses in the harvest stage ...

For the fisheries sector, the application of high technology to production for households in the city is mainly applied in the cultivation of fresh commercial aquatic species of high commercial value such as grass carp., red tilapia, unisexual perch, white shrimp ...; supplying aeration system, using enamel technology to treat the environment, increasing digestion, preventing and treating diseases to support intensive and semi-intensive farming. In recent years, the Center for Agriculture and Forestry Extension has focused on transferring technical advances, applying technologies in freshwater aquaculture such as implementing biosafety fish farming models. Every year, the Can Tho City Farmers Association cooperates with the Economic Department and Can Tho City Agricultural Extension Center to help farmers organize more than 70 training courses on scientific and technological transfer and building new production models.

\section{c. The actual situation of work to support households to consume products}

The implementation of market policies and economic support to households consuming products throughout the city of Can Tho aims to promote, promote, attract investment in production, processing, and consumption of products. Besides, the City Farmer Association cooperates with 


\section{International Journal of Business Management and Economic Review}

Vol. 3, No. 04; 2020

ISSN: 2581-4664

the Economic Department and the City Justice Department in advocating and advocating for legal support to encourage households to sell goods under contracts.

Initially linking economic activities between households went into forming concentrated agricultural production areas as planned; There are many linking models from production to consumption along the value chain. Regarding the consumption of products of non-agricultural households mainly by households, there is an emerging trend of economic development of nonagricultural activities towards export and joint ventures. associating with export units, producing, and processing units for these units. And to have legal status, more convenient in commercial transactions, and also to enjoy incentives for businesses many businesses have registered to become businesses. The city has established an Entrepreneur's Club to create conditions to help and exchange experiences between businesses and support small businesses and small businesses to develop as a bridge for businesses. household businesses receive garment processing contracts, footwear, handicrafts, ...

Product consumption is crucial for the development of household goods production but is currently the weakest. Although the policy has been officially implemented since 2010, until now, the application has not been much. Lack of strategic integration and lack of alignment of policy tools are common. Filling in the picture, linking the production and consumption of products not yet associated with the Decision 80/2002 / QD-TTG on encouraging the consumption of agricultural products through contracts, the Decision 63/2010 / QD-TTG and 65/2011 / QD-TTG on supporting mechanisms and policies to reduce post-harvest losses for agriculture and fishery or financial and credit support mechanisms to link chains ...

Some issues raised in Can Tho City are still the situation where there is no cohesion in production between scientists, the state, entrepreneurs and farmers leading to embarrassment/passive in production organization process; production of products is not yet associated with the consumer market, the market demand leads to an imbalance between supply and demand, "a good crop yields a price loss" - because most households produce traditional agricultural products (self-consumption of products), lack of market information, so do not dare to accelerate production restructuring due to fear of risks; unstable consumption markets, most of the products are consumed by households on the local market or through commercial intermediaries; breach of contract on both sides has occurred, especially for agricultural products, the contracting between farmers and businesses encountered many difficulties. People are not aware of the market.

Table 2.1: Number of households doing business in Can Tho city from 2017 to 2019

\begin{tabular}{|l|l|l|l|}
\hline Manufacturing industry & $\mathbf{2 0 1 7}$ & $\mathbf{2 0 1 8}$ & $\mathbf{2 0 1 9}$ \\
\hline Industry & 4.231 & 5.123 & 4.756 \\
\hline Trade-in Services & 5.321 & 4.756 & 5.012 \\
\hline Agriculture & 2.341 & 5.341 & 5.234 \\
\hline Total & 11.893 & 15.220 & 15.002 \\
\hline
\end{tabular}




\section{International Journal of Business Management and Economic Review}

Vol. 3, No. 04; 2020

ISSN: 2581-4664

\section{Source: Summary of data from Can Tho City Statistical Yearbook 2017 - 2019}

The organization of ensuring market information, economic information, and promotion has not paid enough attention, and market monitoring and supervision have not been implemented well. On the other hand, individual business households in the city area have not invested in the promotion and introduction of commodity products. Through trade fairs by manual methods for agricultural producers to introduce their products, brands and brands have not been built yet to be introduced to the market.

The number of households producing and trading in Can Tho city in 2017 reached 11,893 households, in 2018 reached 15,220 households, in 2019 reached 15,002 households. In general, the growth rate of production and business households is high, especially in agriculture and trade in services.

\section{d. The actual situation of job creation and poverty reduction}

To ensure employment for the people, Can Tho province has focused the political system from the province to the district to propagate the guidelines of the Central Government and the city to implement policies on employment and welfare for people. The province has also set up a mobilization and survey group to approve loans from banks for production and business, vocational training by age, especially male agricultural workers, promptly choosing for them. a job that suits each citizen's aspirations. Also, the city cooperates with departments, agencies, industrial parks, business associations ... to act as a bridge between workers and businesses, especially through employment centers.

Table 2.2: Data of poor households in Can Tho from 2017 to 2019

\begin{tabular}{|l|l|l|}
\hline Year & Number of poor households & Rate (\%) \\
\hline 2017 & 13.041 & 4,25 \\
\hline 2018 & 8.229 & 3,54 \\
\hline 2019 & 4.788 & 2,06 \\
\hline
\end{tabular}

\section{Source: Department of Can Tho Labor - War Invalids and Social Affairs}

Develop a scheme to change industries and create conditions for farmers in areas where the household economy is implemented, such as raising animals and growing crops. In 2019, 3,205 people will have stable jobs) and vocational training will be provided to 2,972 people (Department of Can Tho Labor, War Invalids and Social Affairs, 2019).

Thanks to the measures to promote economic development implemented synchronously, the number of poor households in Can Tho decreases steadily over the years.

\section{A general assessment of household economic development in Can Tho from 2017 to 2019}

\section{a.Successes}

The organization of the implementation of policies on socio-economic infrastructure development in Can Tho province has been attached to the administrative reform. Moreover, the 


\section{International Journal of Business Management and Economic Review}

Vol. 3, No. 04; 2020

ISSN: 2581-4664

implementation of urban planning, infrastructure construction investment, and urban embellishment in the area.

The deployment of science and technology applications in the area through scientific and technical assistance and development of new production models, support of production facilities, training in new technology and techniques, business guidance, legal support for household economic households to gradually switch to cooperatives and businesses, contributing to increased productivity and production efficiency.

Along with that, the process of implementing market policies and supporting the household economy to sell products in Cam Le district has initially linked the households to establish agricultural production areas. According to planning, some linkage models from production to consumption under the value chain are formed.

These efforts in implementing policies have timely created favorable conditions for the production and business activities of households in the district, contributing to accelerating the development and socio-economic growth. associations, reducing poor households, needing poor households in the city.

\section{b. Restrictions}

The lack of strategic integration and the lack of coherent household economic development policy instruments are quite common. In addition to the unclear mechanism and institutional arrangements, the master plan for socio-economic development, urban spatial development planning, infrastructure system planning, and historical planning Land use is in the process of incomplete implementation. The majority of households are weak in a management capacity and limited in financial and technological capacity while it is difficult to access the State's development investment credit capital. The application of science and technology has just stopped in the field of production, and the field of preserving and processing agricultural products after harvest has not been applied by local authorities. Moreover, the organization of market information, economic information, and promotion is not good; weak linkage between product production and consumption market; Most of the products are consumed by households on the local market or through commercial intermediaries.

\section{c. Causes of restrictions}

Many policies just stop at the regulations on papers or the effectiveness is not high, making the links have not promoted the production and business efficiency of the household economy. The tendency of a problem to have too many documents with the same regulations, with the fact that many documents and regulations on a policy make implementation difficult for all stakeholders. Moreover, the lack of review and feedback leads to overlapping, conflicts, and slow improvement in some policies and ineffective implementation. In the strategic planning of Can Tho city, the functions and duties of the departments are quite general, the relationships between the departments in the District and the district leaders and the relationships among the departments are not defined...Besides, there is a lack of a legitimate participation role from the households and the community so that they can be proactive and active throughout the implementation of household economic development policies.

\section{CONCLUSIONS AND RECOMMENDATIONS}




\section{CONCLUSIONS}

The study was conducted to focus on analyzing and assessing the situation of household economic development in Can Tho City in the period of 2017-2019 to identify some limitations and shortcomings in the sustainable development of household economy and its causes, thereby proposing solutions to promote household economy in rural areas in Can Tho City to develop effectively, Sustainable in the coming period from 2021 to 2025.

To achieve the above research objectives, the thesis has clarified the specific objectives as follows:

Systematize theoretical and practical basis for household economic development;

Analyze and assess the current situation of household economic development in Can Tho City in the period from 2017-2019 through contents such as socio-economic infrastructure development; Application and development of science and technology; Supporting households in product consumption; Hunger eradication and poverty reduction from the sustainable household economy.

Proposing solutions to promote household economy in rural areas in Can Tho City to develop towards efficiency and sustainability in the period from 2021 to 2025.

\section{SOME RECOMMENDATIONS}

Based on the findings and conclusions, the following recommendations are suggested:

\section{Solutions for socio-economic infrastructure development}

Can Tho city needs to continue investing, building and completing a synchronous infrastructure system in the area; coordinate with functional branches to review and propose the city to adjust the inadequacies in the planning, accelerate the construction progress of complete infrastructure of residential areas; further develop socio-economic infrastructure to facilitate trade and service development.

Regarding agriculture: First of all, it is necessary to concentrate investment on building infrastructure in specialized vegetable growing areas of the province. Based on balancing production areas and the investment needs of each vegetable-specialized region, there are plans to invest in suitable works such as roads, electricity, mobile nets, irrigation tanks, irrigation systems, etc. Avoid wasteful investment that is not effective. It is advisable to invest in infrastructure facilities that serve the whole community of producers in vegetable areas for investment other than the purpose of serving specialized vegetable production, specifically investing in some areas such as After: For Can Tho Clean Vegetable Garden (Can Tho Farm): Coordinate with the city in developing the necessary infrastructure investment plan in the vegetable area in the direction of modern vegetable-growing areas from the capital of the city. city and ODA loans. Besides, it is possible to synchronously plan and invest in infrastructure in BinhThuy district, combining sightseeing tours to have more income from vegetable gardens.

Implementing and maintaining the "Green-Clean-Nice Sunday" movement, collecting waste by the hour; basically deal with the inundation spots, environmental pollution in the area, develop greenery in parks, public land areas, and regulating lakes into green spaces to serve people's daily needs; socialize planting and tending trees on some roads; gradually move polluting enterprises in residential areas into concentrated industrial clusters. 


\section{International Journal of Business Management and Economic Review}

Vol. 3, No. 04; 2020

ISSN: 2581-4664

\section{Solutions for application and development of science and technology}

Improving the dissemination and application of science and technology in business and production, especially in agricultural production (applying new technology for manufacturing and processing, providing material services). There are specific scientific and technological research and application programs for each specific district and town, to serve farmers' households. The areas specializing in high-quality vegetables, flowers, and rice-growing under the planning should initially have a synchronous investment policy on infrastructure, supporting breeds and techniques to help people bravely and safely invest in the development. production. New agricultural production models that apply for scientific and technical advances, new breeds should have support policies such as technical training, initial seeds, and partial funding support when risks arise to help people feel secure, focus on production. Promote and consolidate agricultural extension centers, research new animal and plant varieties that bring high efficiency, effectively transfer to farmers.

Reform the working mechanism of the agricultural extension system, create material motivation, and link the benefits of extension workers with production efficiency in the area. Complete the policy of encouraging highly trained and technically qualified staff to work in hi-tech agricultural production. In particular, regularly attaching importance to training cooperative staff of general production and business services in the city with sufficient qualifications and capacity to support farmers in production.

Open an average of 1 training course on basic management skills and technical skills for local agricultural management staff to provide management knowledge to support farmers in production in agriculture, proactively handle in time the situations that occur and be strong enough to carry out the function of advising the local leaders in agricultural development orientation.

It is necessary to supplement and study the application of regulations on preferential support for agricultural production households in applying post-harvest technologies: preserving and processing agricultural products; as well as supplementary regulations supporting the preferential application of science and technology for non-agricultural production households ... to complete a step in promoting the implementation of the policy of transferring scientific and public advances. Technology for household economic development.

At the same time, strong investment in education and training is a strategy of the majority of households to enable the young labor force to escape to find new jobs. This is the most fundamental and critical issue to develop a sustainable household economy, transforming the production model from household economy to a higher form. Therefore, it is necessary to promote investment in raising qualifications through supportive policies, encouraging farmers to learn vocational skills, restructure labor, and create favorable conditions for farmers to switch to industry and translation. To improve the labor productivity of households. Particularly for people directly engaged in agricultural production, there should be a plan to open many short-term and long-term training courses in each of the high technology fields and new scientific and technological advances to Help farmers apply in production.

Strengthening vocational training and vocational training programs for farmers in terms of production techniques (focusing on supporting production, providing extension services, forestry, fishery ...) and economic management, knowledge of laws, markets, and international 


\section{International Journal of Business Management and Economic Review}

Vol. 3, No. 04; 2020

ISSN: 2581-4664

integration ... New effective agricultural development models should be held to encourage farmers to expand the model. For production groups and groups, training on methods of production planning and administration and access to consumer markets should be trained. Each year, there are plans for 5-10 intensive training courses for extension workers, Farmers' Association who directly approach and guide farmers in production. Extension workers and Farmers' Association are the bridge between scientists, managers, and farmers, helping farmers quickly access to scientific and technical advances. Therefore, the training of agricultural extension workers is even more important to the process of developing an urban agricultural economy, producing competitive agricultural products in an integrated environment.

Promote the relationship between scientists - households - businesses in the transfer of application of science and technology in the production and consumption of goods (linking production and product consumption). Strengthening the relationship between households and between households and businesses is also an important condition for developing a sustainable household economy.

\section{Solutions to support households to consume products}

In the context of market mechanisms and economic integration, competition is becoming more and more fierce. Therefore, the role of market development is more important than ever. If production development is not associated with market development to solve the "output" of consumption of products and services, it will face unpredictable risks for economic entities. The market is the decisive factor to exploit the potential of the household; The greater the orientation of household economic production to meet market demand, the greater the ability to benefit households from production activities. The consumer market is a particularly important issue for the development of agricultural production today.

The State has the policy to support the search and expansion of product markets for household and farm economies, which are necessary and urgent when the scale of production is on the rise. Therefore, priority should be given to designing and implementing policies to mobilize market mechanisms so that the household economy can be proactive and sustainable. Policies to support market development for the household economy used by local governments should focus on support for finding partners and output markets for their products and services.

Local authorities organize activities (exhibitions, fairs, ...) to create opportunities to promote products and services of the household economy to potential customers inside and outside the locality. Much attention should be paid to the role of the State's supportive policy in providing timely and complete information to households about market fluctuations that will help households capture new business opportunities to minimize the risk of "devaluation season"; at the same time help households easily consume the products they produce ...

The city's current scale of agricultural production is moderate and food safety is an opportunity for the development of clean high-tech agriculture in the future to serve a large number of urban dwellers. like tourists in Can Tho city. Currently, the city has supermarkets, markets, and diverse restaurants that can be the ideal destinations for agricultural products of the province.

On the other hand, the city government should have a policy of developing stores to introduce and sell specialty agricultural products of the city as well as of Can Tho city to expand the channels of marketing and consumption of local agricultural products. Phuong. For example, clean products such as organic rice, clean vegetables, safe food, organic restaurants, eco 


\section{International Journal of Business Management and Economic Review}

Vol. 3, No. 04; 2020

ISSN: 2581-4664

restaurants, and eco-labeled agricultural products.

Besides, the household economy as a certifier of production and business households is in the small-sized business sector. Therefore, it is time to consider the study of individual business households on their legal status to regulate their legitimacy in this policy to pave the way for a better household economy. signed with partners in production and business investment

The main labor members themselves in individual business households need to raise awareness to be fully aware of the market (both advantages and risks due to its impact) on a first-come, first-served basis. from planning (strategy) to build product brands, own brands, and invest in seeking potential consumer markets (avoiding investment in a trendy fashion).

Through market policies and support to the consumption of products by the State, it helps the household economy adapt to the market mechanism, contributing to improving the efficiency of using labor resources, creating jobs in the countryside; as well as stimulating households to produce based on family farms, in the fields of agriculture - forestry - fishery ...

\section{Solutions for sustainable poverty reduction from the sustainable household economy}

The current agricultural households in Vietnam in general and in Can Tho in particular tend to oversupply labor due to a decrease in cultivated land. Therefore, it is necessary to reorganize the division of labor, labor, and industry restructuring to restructure the household economy, paying attention to the career transition trend of rural households. from agriculture to handicrafts, services, and other non-agricultural occupations with leading characteristics. In this career transition process, the individual factor of the employee plays an important role. The young generation workers with high school education or higher in rural areas tend to escape more and more. Therefore, the household economy can only be promoted and developed sustainably under appropriate and timely policies. Households can develop their economy independently, but cannot develop on a large scale and sustainably without appropriate government policies. Therefore, the development of the household economy must be associated with the construction of new rural areas, the implementation of diversification of industries, rising incomes, and living standards. In principle, the restructuring of a household's business is moving from purely agricultural business to general business or specialized business, but choosing a specific industry is stable and feasible. Based on market demand, taking into account the advantages of each locality.

Promote investment to improve the qualifications and labor productivity of households. Relevant units should regularly organize technical training and increase investment in expanding vocational training facilities for young people, especially in rural areas in Can Tho province.

\section{REFERENCES}

1. Can Tho City Party Executive Committee (2018), Report on the results of the implementation of the Resolution of Can Tho City's 20th Party Congress, socio-economic development directions and tasks of City to 2025 .

2. Report on the results of 5 years of implementation, Scheme on renovating and raising the operational efficiency of the Farmers Support Fund for the period 2015 - 2025 "of Can Tho city. 3. Can Tho city development project and strengthening the adaptability of the urban area (2019) Can Tho Provincial People's Committee 
International Journal of Business Management and Economic Review

Vol. 3, No. 04; 2020

ISSN: 2581-4664

4. Statistical Yearbook of Can Tho Province in 2017, 2018, 2019

5. Decision 80/2002 / QD-TTG on encouraging the consumption of agricultural products through contracts.

6. Decision 2324 / QD-UBND. (2019) Promulgating a list of sectors of socio-economic infrastructure investment in development priority of Can Tho city, Can Tho province

7. Decision 63/2010 / QD-TTG and 65/2011 / QD-TTG on supporting mechanisms and policies to reduce post-harvest losses for agriculture and fishery or financial and credit support mechanisms used to chain connection.

8. Department of Can Tho Labor, War Invalids and Social Affairs (2019), Report on implementation of poverty reduction

9. Can Tho provincial People's Committee, Socio-Economic Survey Report 2019 